\title{
The significance of the retinal artery pressure in cerebrovascular insufficiency
}

\author{
J.SZAPIRO AND I. ŚWIETLICZKO \\ From the Neurosurgical and Ophthalmological Clinics, Medical Academy, Lódz, Poland
}

Arterial ophthalmodynamometry has become a popular test in cases of carotid occlusion. Growing experience has, however, aroused some doubts as to its usefulness (Hollenhorst, 1959; Croll, Hardy, Lindner, Webster, and Gurdjian. 1960; Tindall, Dukes, Cupp, and David, 1960; Ross Russell and Cranston, 1961 ; Liversedge and Smith, 1961). These criticisms, consequent on the occurrence of misleading results, were at least partly due to insufficiency of data concerning the various and changing behaviour of the retinal artery pressure in relation to carotid occlusion. For this reason, it seemed justified to analyse this problem and to widen its scope in time and place by making repeated examinations of patients with carotid occlusion or with occlusive lesions located in other arteries on the heart-to-brain route under varying conditions. This study is based on the anatomical features of what may be described as the anterior aorto-cerebral circle (Szapiro, 1960). We used Sobański's ophthalmodynamometer.

The clinical expectation in cases of occlusion of one internal carotid artery is that the retinal artery pressure should be lower on the ipsilateral side, and the terms 'false positive' or 'false negative' have been used to describe the exceptions to this expected rule. However, there are no anatomical or physiological reasons to apply these terms to cases, which after all proved to be not infrequent. It would be more correct to state that the presence of a marked difference between the retinal artery pressure levels in both eyes is compatible with a diagnosis of an occlusion located in any portion of the anterior aorto-cerebral circle, from the aortic arc up to the retinal artery, as was revealed in many cases. The exact site may be determined subsequently in correlation with eye fundic changes and the behaviour of the pulsation of the carotid, superficial temporal, and radial arteries. On the other hand, in cases with unilateral carotid occlusion one third of the patients had retinal artery pressure levels which were equal in the two eyes (Hollenhorst, 1959). It is, however, important to appreciate that collateral circulation from the opposite internal carotid artery or via the ipsilateral carotid artery to the ophthalmic artery may be quite good and may account for the 'false' findings. Further, there are special methods whereby $\vec{\sigma}$ these cases may also be forced to provide important $\varrho$ information of localizing value, as was pointed out $\mathrm{\omega}$ by Milletti in 1946. Such possibilities were also $\vec{\circ}$ confirmed by our own experience (Świetliczko and Szapiro, 1960; Swietliczko and Szapiro, 1961; $\vec{\omega}$ Šwietliczko, Szapiro, and Polis, 1961) as well as by윽 Lowe and Stephens (1961) and by Segał, Bromowicz, Adamczewska, Krawczyk, and Strzałko, (1961).

The special methods of diagnosis in these cases depend on performing the carotid compression test during determination of the retinal artery pressure. $\overrightarrow{0}$ Our investigations, carried out in healthy persons anel 윽 in patients with middle cerebral artery occlusion have confirmed, as described in the literature, tha during the compression of any of the carotid arteries $\frac{9}{0}$ the retinal artery pressure falls in the ipsilateral exe and rises in the opposite one (Fig. 1a) (Heyma fr. Karp, and Bloor, 1957; Swietliczko, Waleszkowsk and Polis, 1960; Swietliczko, 1962). These results are $\omega$ reliable provided certain differences, depending on the age of the patient, his position, duration of the compression, and behaviour of the systolic versus the diastolic pressures, are taken into account. This pattern of behaviour during the carotid compression $\stackrel{2}{\perp}$ test showed some deviations in another series of our $\overrightarrow{\vec{A}}$ cases in which an occlusive lesion narrowed the lumen $\frac{1}{3}$ of arteries located in the portion of the anterior aorto-cerebral circle situated between the ophthalmic arteries. Thus in cases of partial occlusion of the proximal part of the anterior cerebral artery the compression of any of the carotid arteries caused a fall of retinal artery pressure in the ipsilateral eye, while in the opposite eye it remained unchanged (Fig. 1b and Table I).

A definite change in the pattern of retinal artery pressure during the carotid compression test was observed in cases in which a carotid occlusion was $\frac{D}{O}$ masked by equal retinal artery pressure levels in both eyes. Since in these cases the collateral circula- $\tilde{N}$ tion is supplied mostly by the opposite carotit artery, its compression caused a fall in retinal artery pressure not only on the ipsilateral side but 

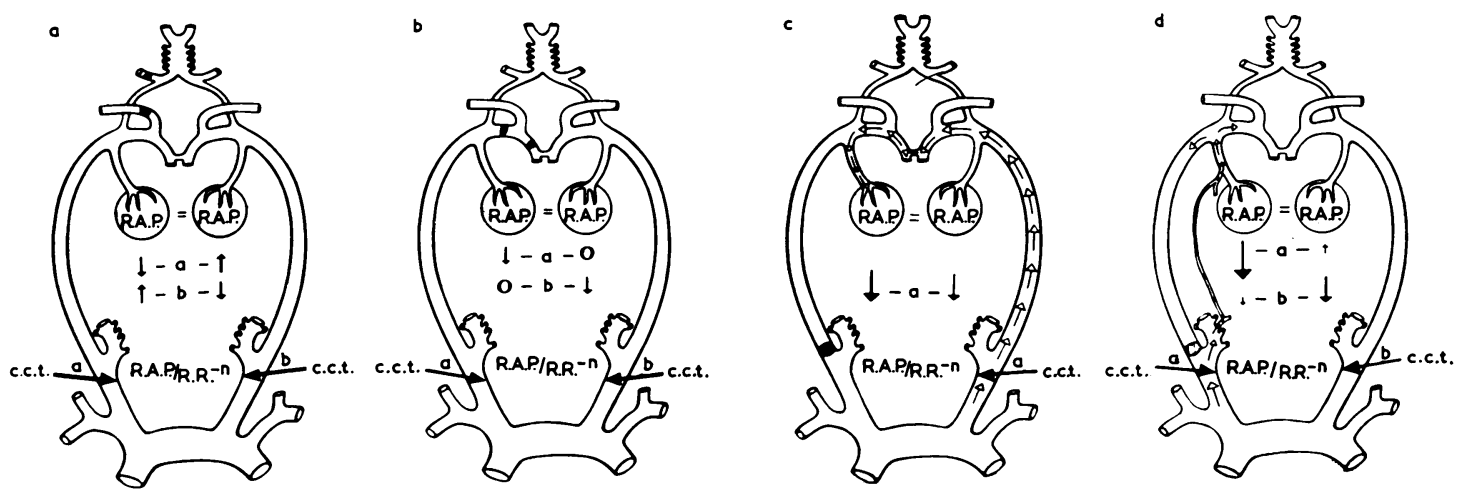

FIG. 1. Cases of occlusion, with equal retinal artery pressures in both eyes, in which the diagnosis depends on performing the carotid compression test. a Occlusion of the middle cerebral artery (or posterior cerebral artery). b Occlusion of the proximal part of the anterior cerebral artery (or in the terminal segment of the internal carotid artery). c Internal carotid artery thrombosis with main collateral blood supply from the opposite carotid artery. $\mathrm{d}$ Internal carotid artery thrombosis with main collateral blood supply from the ipsilateral external carotid artery.

also on the side of the occlusion (Fig. 1c and Table II). Indeed this pattern, although most commonly observed, should not be considered as the only possibility, for the contribution of the vertebralbasilar system, and particularly of the external carotid artery ipsilateral to the occlusive lesion, to the collateral blood supply of the ophthalmic and retinal arteries must be borne in mind. So, in one of our cases of internal carotid thrombosis during the compression of the opposite carotid artery the fall in retinal artery pressure on the side of occlusion was not as marked as during compression on the ipsilateral side (Fig. 1d), when a sudden blanching of the ocular fundus and collapse of the arteries was observed. Thus in this case the principal role of the external carotid artery as a source of a collateral circulation was demonstrated.

It is evident that in all examinations in which the carotid compression test is performed the general blood pressure has to be measured simultaneously because of the changes sometimes induced by mani- pulations in the region of the carotid sinus. Failure to consider this in interpreting the retinal artery pressure measurements might result in diagnostic errors. Also in routine ophthalmodynomometric examinations the general blood pressure should always be recorded. The relation of the retinal artery to the general blood pressure is supposed to be constant, and deviations in any direction may be of diagnostic value, suggesting the occlusion of either the internal carotid arteries or of the basilar circulation.

Our studies seem to indicate that in cases of nonsurgical occlusion determination of the retinal artery pressure may be of increased diagnostic value if approached from the wider aspects described. Certainly, the problem of the potential danger of the test must not be underestimated.

Another group of cases in which the value of ophthalmodynamometry should be considered concerns patients with carotid ligation. The old saying that this operation is a shot in the dark may, in our opinion, be applied even more to the post-operative

TABLE I

RESULTS OF THE RETINAL ARTERY PRESSURE DETERMINATIONS IN CASES OF OCCLUSION OR STENOSIS OF PROXIMAL PART OF ANTERIOR CEREBRAL ARTERY ${ }^{1}$

\begin{tabular}{|c|c|c|c|c|c|c|}
\hline \multirow[t]{3}{*}{ Patient } & \multirow{2}{*}{\multicolumn{2}{|c|}{$\begin{array}{l}\text { Retinal Artery Pressures }(\mathrm{mm} . \mathrm{Hg}) \\
\text { before Carotid Compression Test }\end{array}$}} & \multicolumn{4}{|c|}{ Retinal Artery Pressure Changes ( $\%$ ) } \\
\hline & & & \multicolumn{2}{|c|}{ During Right Carotid Compression } & \multicolumn{2}{|c|}{ During Left Carotid Compression } \\
\hline & Right Eye & Left Eye & Right Eye & Left Eye & Left Eye & Right Eye \\
\hline $\begin{array}{l}\text { K.T. } \\
\text { W.T. } \\
\text { K.A. } \\
\text { P.A. } \\
\text { P.C. } \\
\text { J.A. }\end{array}$ & $\begin{array}{r}80 / 40 \\
82 / 56 \\
102 / 48 \\
/ 58 \\
84 / 52 \\
86 / 52\end{array}$ & $\begin{array}{r}84 / 42 \\
82 / 56 \\
102 / 52 \\
158 \\
84 / 50 \\
82 / 52\end{array}$ & $\begin{array}{l}35 \\
36 \\
65 \\
40 \\
75 \\
75\end{array}$ & $\begin{array}{l}0^{2} \\
0 \\
0 \\
0 \\
0 \\
0\end{array}$ & $\begin{array}{l}30 \\
73 \\
51 \\
54 \\
75 \\
58\end{array}$ & $\begin{array}{l}0 \\
0 \\
0 \\
0 \\
0 \\
0\end{array}$ \\
\hline
\end{tabular}

1No changes or changes within limits of error. In cases of changes in general blood pressure level during the test the percentage of the fall or rise in retinal artery pressure was adequately computed. 
TABLE II

RESULTS OF RETINAL ARTERY PRESSURE DETERMINATIONS DURING COMPRESSION OF OPPOSITE CAROTID ARTERY IN CASES OF CAROTID OCCLUSION OR STENOSIS WITH EQUAL RETINAL ARTERY PRESSURES IN BOTH EYES ${ }^{1}$

Patient Diagnosis

\begin{tabular}{|c|c|c|c|c|c|}
\hline & \multirow[t]{2}{*}{ 年 } & \multicolumn{2}{|c|}{$\begin{array}{l}\text { (mm. Hg) before Carotid } \\
\text { Compression Test }\end{array}$} & \multicolumn{2}{|c|}{$\begin{array}{l}\text { Pressure Fall }(\%) \text { during } \\
\text { Compression of Patent } \\
\text { Carotid Artery }\end{array}$} \\
\hline & & $\begin{array}{l}\text { On Side of } \\
\text { Occlusion }\end{array}$ & $\begin{array}{l}\text { On Opposite } \\
\text { Side }\end{array}$ & $\begin{array}{l}\text { On Side of } \\
\text { Compression }\end{array}$ & $\begin{array}{l}\text { On Side of } \\
\text { Occlusion }\end{array}$ \\
\hline $\begin{array}{l}\text { S.W. } \\
\text { H.M. } \\
\text { B.J. } \\
\text { D.W. } \\
\text { S.J. } \\
\text { M.A. }\end{array}$ & $\begin{array}{l}\text { Right internal carotid thrombosis verified by angiogram } \\
\text { Left internal carotid thrombosis verified by angiogram } \\
\text { Left internal carotid stenosis verified by angiogram } \\
\text { Right common carotid ligation } \\
\text { Right common carotid ligation } \\
\text { Right common and internal carotid ligation }\end{array}$ & $\begin{array}{r}96 / 62 \\
80 / 52 \\
62 / 40 \\
176 \\
106 / 44 \\
76 / 58\end{array}$ & $\begin{array}{r}96 / 66 \\
78 / 52 \\
62 / 40 \\
176 \\
106 / 48 \\
76 / 56\end{array}$ & $\begin{array}{l}38 \\
50 \\
60 \\
50 \\
64 \\
38\end{array}$ & $\begin{array}{l}36 \\
49 \\
19 \\
35 \\
26 \\
41\end{array}$ \\
\hline
\end{tabular}
${ }^{1}$ No changes or changes within limits of error. In cases of changes in general blood pressure level during the test the percentage of the fall or $\cong$
rise in retinal artery pressure was adequately computed.

period during which the direct intra-arterial measurements of the blood pressure distally to ligation may only be performed once or twice. On the other hand, determination of the retinal artery pressure, even if less direct, may provide a continued control of the effect of the carotid ligation and of the collateral circulation efficiency for an unlimited period of time since it may be performed as often as necessary (Szapiro and Swietliczko, 1960). This method may be of assistance before the proposed ligation, for the retinal artery pressure changes induced during a carotid compression test may suggest the choice of the operative procedure. The value of this examination obviously rises during the operation, for in some cases it may be the best or even the only method of indicating which one of the carotid arteries, the common or the internal, should be ligated and whether the ligation has to be complete. During the immediate post-operative period, determination of the retinal artery pressure may suggest the possibility of some slipping of the ligature or even the necessity for its removal. In cases in which instead of ligation a carotid clamp is temporarily used the tightening or $\vec{\exists}$ releasing this clamp according to the change in the ${ }_{\sigma}^{\omega}$ retinal artery pressure level is most useful. The continued ophthalmodynomometric control of the patient may sometimes suggest the necessity of $\mathrm{N}$ introducing modifications in conservative treatment ir or even of performing an additional operation cases in which the equalization of retinal arte pressure in both eyes has taken place too early. 角윽 our patients three variants of behaviour in reting artery pressure after carotid ligation could observed (Fig. 2). In some, it equalized in bogh 0 eyes almost immediately, whereas in others the happened after several weeks, months, or even years; in the last group no equalization was noted during the follow-up period of several years.

The survey of cases of carotid ligation seems then to show that determination of the retinal artery pressure may be of remarkable value, and by increasing the margin of safety will increase the efficiency of the procedure and contribute to the prevention of operative complications.

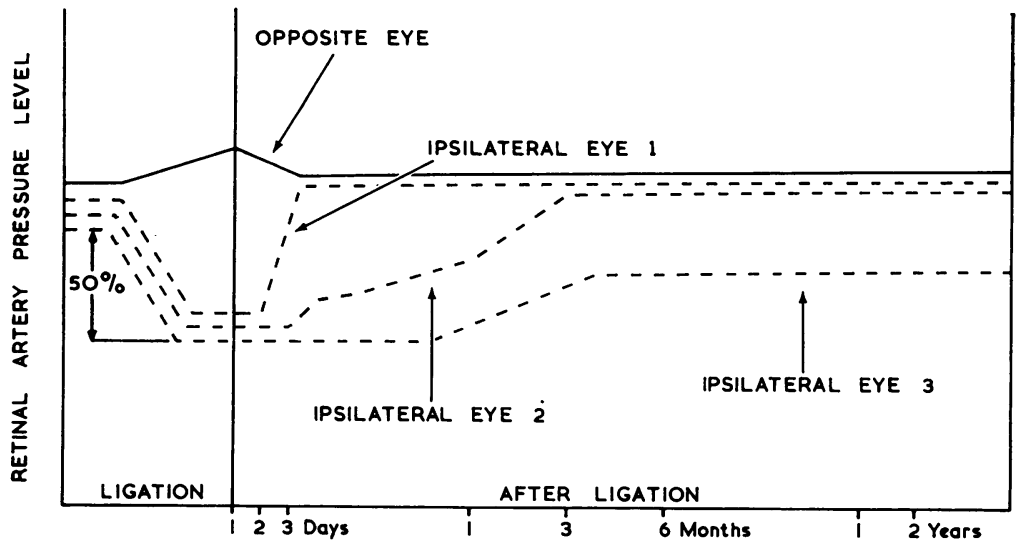

FIG. 2. Three variants in the behaviour of the retinal artery pressure after carotid ligation. 
TABLE III

CORRELATION OF ARM-TO-RETINA FLUORESCEIN DYE TEST WITH CIRCULATION TIME AND RETINAL ARTERY PRESSURE DETERMINATION

\begin{tabular}{|c|c|c|c|c|c|c|c|}
\hline \multirow{2}{*}{\multicolumn{2}{|c|}{ Patient }} & \multirow{2}{*}{\multicolumn{2}{|c|}{ Age and Sex }} & \multirow[t]{2}{*}{ Site } & \multirow{2}{*}{$\begin{array}{l}\text { Time after Ligation } \\
\text { (or First Signs of } \\
\text { Occlusion) }\end{array}$} & \multicolumn{2}{|c|}{ Difference between Both Sides } \\
\hline & & & & & & $\begin{array}{l}\text { Retinal Arterial } \\
\text { Pressure }(\%)\end{array}$ & $\begin{array}{l}\text { Circulation Time } \\
\text { (Seconds) }\end{array}$ \\
\hline \multicolumn{8}{|c|}{ Carotid ligation } \\
\hline 1 & B.R. & 23 & $\mathbf{M}$ & Left common & $3 \mathrm{mth}$. & 40 & $3 \cdot 5$ \\
\hline 2 & F.B. & 22 & $\mathbf{F}$ & Left internal & $9 \mathrm{yr}$. & 36 & 1.7 \\
\hline 3 & C.B. & 35 & $\mathbf{M}$ & Left common & $4 \mathrm{mth}$. & 25 & $2 \cdot 6$ \\
\hline 4 & M.A. & 48 & $\mathbf{M}$ & Right common and internal & $2 \mathrm{yr} .4 \mathrm{mth}$. & 21 & 1.5 \\
\hline 5 & K.G. & 41 & $\mathrm{~F}$ & Right common & 5 mth. & 20 & $1 \cdot 0$ \\
\hline 6 & J.M. & 53 & $\mathbf{F}$ & Right common (incomplete) & $3 \mathrm{yr}$. & 20 & $2 \cdot 0$ \\
\hline 7 & M.S. & 39 & $\mathbf{F}$ & Left common & 2 yr. 5 mth. & 18 & $3 \cdot 0$ \\
\hline 8 & K.B. & 50 & $\mathbf{M}$ & Right common & $3 \mathrm{yr}$. & 13 & $1 \cdot 2$ \\
\hline 9 & S.J. & 63 & $\mathbf{M}$ & Right common & 2 yr. 3 mth. & 10 & $3 \cdot 0$ \\
\hline 10 & J.A. & 66 & $\mathbf{M}$ & Right common & $4 \mathrm{yr}$. & 10 & 0.4 \\
\hline 11 & K.A. & 40 & $\mathbf{F}$ & Left common & $4 y r .4 \mathrm{mth}$. & 10 & 0 \\
\hline 12 & K.M. & 37 & $\mathbf{F}$ & Right common and internal & $1 \mathrm{yr} .3 \mathrm{mth}$. & $\mathbf{0}$ & 1.8 \\
\hline 13 & D.N. & 39 & $\mathbf{M}$ & Right common & $2 \mathrm{yr}$ & 0 & $1 \cdot 2$ \\
\hline \multicolumn{8}{|c|}{ Occlusion } \\
\hline & N.H. & 36 & $\mathrm{~F}$ & Right internal carotid & $4 \mathrm{mth}$. & 40 & $2 \cdot 4$ \\
\hline 2 & S.I. & 49 & $\mathbf{M}$ & Left internal carotid, right subclavian & $2 \mathrm{yr}$. & 27 & $4 \cdot 6$ \\
\hline & B.C. & 59 & $\mathbf{M}$ & Left internal carotid (incomplete right & & & \\
\hline & & & & subclavian) & $2 \mathrm{yr}$. & & $3 \cdot 8$ \\
\hline
\end{tabular}

In discussing the pressure changes noted distally to occlusive lesions, the problem of the blood flow should not be forgotten. We have not had the opportunity of correlating the pressure with the blood flow, as measured by electromagnetic flowmeter, and besides, this method can be used only once or twice in one patient. For this reason we found it logical to correlate the retinal artery pressure determination with the arm-to-retina fluorescein test which was previously applied by David, Saito, and Heyman (1961) and by Hollenhorst and Kearns (1961) as a diagnostic aid in cases of suspected carotid occlusion. Some recent as yet unpublished data achieved by the use of the blood flowmeter seem to suggest a correlation between a decrease in the blood pressure and of slowing down of the blood flow. In our studies this fact could not be confirmed, as is shown in Table III. The problem of accuracy of the fluorescein test is still to be solved and further studies are required before reliable practical conclusions can be drawn.

Finally several facts should be mentioned as revealed by the correlation of the ophthalmodynamometric data with the clinical and angiographic findings. This correlation seems to suggest that although occlusion of the collateral circulation in cases of carotid occlusion is one of the principal causes of inequality of retinal artery pressures in both eyes, nevertheless the patency of these channels should by no means be considered as a guarantee of equalization of the retinal artery pressures. Certain data found in these cases suggest that the factor responsible for the inefficacy of collateral circulation need not always be mechanical in nature. Two general conclusions may be drawn from these findings: First, the development of a neurological or ophthalmological deficit may be caused both by occlusion of a cerebral or retinal artery, and by their isolation. This possibility may be due to the combined effect of occlusive lesions located in sources remote from these arterial pathways and in collateral circulation channels. Secondly, the development of transient ischaemic symptoms may be caused both by the embolic process and by a haemodynamic crisis.

\section{REFERENCES}

Croll, M., Hardy, W. G., Lindner, D. W., Webster, J. E., and Gurdjian, E. S. (1960). J. Neurosurg., 17, 394.

David, N. J., Saito, Y., and Heyman, A. (1961). Arch. Neurol., 5, 165.

Heyman, A., Karp, H. R., and Bloor, B. M. (1957). Neurology (Minneap.), 7, 97.

Hollenhorst, R. W. (1959). Amer. J. Ophthal., 47, 753.

- and Kearns, T. P. (1961). Proc. Mayo Clin., 36, 457.

Liversedge, L. A., and Smith, V. H. (1961). Brain, 84, 274.

Lowe, R. D., and Stephens, N. L. (1961). Lancet, 1, 1241.

Milletti, M. (1946). Presse méd., 54, 655.

Russell, R. W. Ross, and Cranston, W. I. (1961). J. Neurol. Neurosurg. Psychiat., 24, 281.

Segal, P., Bromowicz, J., Adamczewska, Z., Krawczyk, Z., and Strzałko, M. (1961). Klin. oczna., 31, 117.

Świetliczko, I., and Szapiro, J. (1960). Ibid., p. 20. Lódź (L.T.N.).

$\longrightarrow,-$, (1961). Klin. oczna, 31, 105.

- _ a a - a Polis, Z. (1961). Amer. J. Ophthal., 52, 862.

(1962). Rola $i$ wartośc pomiarów cisnienia w tetnicy środkowej siatkôwki w rozpoznawaniu zakrzepicy tetnicy szyjnej wewnetrznjej. Lódź (L.T.N.)

—, Waleszkowski, J., and Polis, Z. (1960). Ibid., p. 25. Lódź (L.T.N.).

Szapiro J. (1960). In Z. Zagadnien Fizjopatologii Krażenia Krwi w Mózgu, p. 54. Lódź (L.T.N.).

$\longrightarrow$, and Swietliczko, I. (1960). Ibid., p. 15. Lódź (L.T.N.).

Tindall, G. T., Dukes, H. T., Cupp, H. B., and David, N. J. (1960). Neurology (Minneap), 10, 623. 